\title{
APPLYING INTELLECTUAL CAPITAL IN IMPROVING AGRI-INDUSTRY AT REPUBLIC OF SERBIA
}

Sonja D. Radenković ${ }^{1}$, Jelena Šaranović ${ }^{2}$, Boban Stojanovic ${ }^{3}$, Zorana Kostić ${ }^{4}$, Bojan Jokić ${ }^{5}$

*Corresponding author E-mail: sonjafon@gmail.com

\begin{abstract}
A R T I C L E I N F O
A B S T R A C T

Original Article

Received: 10 May 2018

Accepted: 11 June 2018

doi:10.5937/ekoPolj1802659R

UDC 005.96:338.43(497.11)

Keywords:

economic framework, business environment, barriers, intellectual capital

JEL: 034

Analysis of the economic framework for doing business between Serbia and Autonomous Province of Kosovo and Metohija, that is under the interim civil and military administration of the United Nations, according to UN Resolution 1244 (hereinafter referred to as Kosovo*) aims to point of the need to eliminate barriers in doing business between Serbia and Kosovo*, making recommendation for improving the business environment. The research involved experts analyzed legal regulations governing the business environment in Kosovo* and carried out the research. They interviewed business people and representatives of companies from central Serbia and Kosovo*. The results of the survey enable the creation of a wider picture of company operations when crossing of the administrative crossings, identifying disturbances in the passage of goods and services, as well as formulating proposals to overcome existing barriers in doing business between business entities in central Serbia and the Autonomous Province of Kosovo and Metohija.
\end{abstract}

(C) 2018 EA. All rights reserved.

\section{Introduction}

In the accession process towards the European Union, the Republic of Serbia has opened twelve chapters until the end of 2017. Within the framework of the accession negotiations, Chapter 35 on other issues - "normalisation of relations between Serbia and Kosovo*" was opened in December 2015. In order to adequately monitor the

1 Sonja D. Radenković, PhD, Professor, College of Economics Peć-Leposavić, Dositeja Obradovića bb, 38218 Leposavić, Phone: +381 2883 780, e-mail sonjafon@gmail.com

2 Jelena Šaranović, PhD, Professor, College of Economics Peć-Leposavić, Dositeja Obradovića bb, 38218 Leposavić, Phone: +381 2883 780, e-mail: jelsaranov@gmail.com

3 Boban Stojanović, PhD, Full Professor, University of Niš - Faculty of Economics, Trg Kralja Aleksandra Ujedinitelja, 18000 Niš, Phone: +381 18528 601, e-mail: dr.boban.stojanovic@gmail.com

4 Zorana Kostić, Assistant, University of Niš - Faculty of Economics, Trg Kralja Aleksandra Ujedinitelja, 18000 Niš, Phone: +381 18528 601, e-mail: zoksinis@gmail.com

5 Bojan Jokić, Professor, College of Economics Peć-Leposavić, Dositeja Obradovića bb, 38218 Leposavić, Phone: +381 2883 780, e-mail: bojan.jokic@yahoo.com 
economic relation between Serbia and its autonomous province Kosovo and Metohija, that is under the interim civil and military administration of the United Nations, according to UN Resolution 1244 (hereinafter referred to as Kosovo*), it is necessary to look at the macroeconomic and business environment, as a whole. This analysis has very high importance which stems from the need to improve the economic environment and point out the need for elimination the barriers in business operations. In this paper the focus is in on the agro-industry, as one of the most perspective branches in Republic of Serbia. The aim is to emphasize the importance of using intellectual capital in this area as the knowledge that needs to leverage into the market value (Roos et al., 1997; Spender and Grant, 1996). There are three basic components of intellectual capital: human capital, structural capital and relational capital (Martín de Castro, G et. al., 2005). Human capital is the knowledge which groups or people possess, as well as their ability to generate and reinforce it. Structural capital refers to the combination of knowledge and intangible assets derived from the processes of action which are property of the organization and which remain in it. Finally, the heterogeneity of external agents recommends the explicit distinction between business capital and social capital, both included in the relational capital component as can be seen in (Euroforum, 1998; Bueno, 2001), or in the customer capital (Stewart, 1997). Both human capital, structural capital, as well as relational capital are very important in the overcoming the barrier between the agro-industrial actors in both sides.

It has often highlighted that trade of agricultural products and livestock is difficult due to EULEX insists on compliance with EU rules, whilst many products from Serbia do not meet EU standards required in Kosovo*. Namely, only 6 out of 30 slaughter houses in Serbia meet EU requests and standards. This shows that this sector in Serbia is not yet ready for EU integration, so that institutions such as the Chamber of Commerce and other associations of agricultural producers should devote efforts to remove this deficiency. This is in the interest of development of agriculture and livestock farming in Serbia itself, because they will be able to export products to Kosovo* market as well as the broader market like the EU. This is relevant for Kosovo*due to about $60 \%$ of its population is rural, and agriculture accounts from $25 \%$ to $35 \%$ of the total employment, and agricultural arable land accounts for about 53\% of the entire territory. However, agriculture accounts for only $12.9 \%$ of GDP.

Agricultural production is largely of mixed type, it uses very old, traditional methods and it is in efficient. Livestock has almost disappeared, farm machinery is damaged, and production equipment is obsolete. There is great potential for the development of all types of agriculture in North Kosovo*. The potential is still insufficiently used primarily due to a low level of education of farmers, fragmented agricultural land, insufficient or very poorly maintained irrigation systems, limited capacity for processing and marketing of agricultural products. Animal husbandry, like agriculture, is faced with the difficulty of obtaining raw materials, insufficient application of animal husbandry technology, poorly developed infrastructure and outdated approach. In order to move from the individual to highly efficient production it is necessary to invest in 
specialized farms, mini-farms, which have self-sustaining resources, it is necessary to establish a network of control and veterinary care, as well as to search for solutions through associations of farmers.

\section{Analysis of the economic framework for doing business between Serbia and} Kosovo*

The legal and regulatory framework applied to exchange of goods with Kosovo* is based on the following documents:

- Regulation on special conditions for the circulation of goods with Kosovo*;

- Regulation on Enforcement of the Law on VAT in the territory of Kosovo for as long as the UN Security Council Resolution 1244 is effective;

- Regulation on Enforcement of the Law on Excise Duties in the territory of Autonomous Province of Kosovo* for as long as the UN Security Council Resolution 1244 is effective Article 309 of the Customs Law (Official Gazette of RS, No. 18/2010 and 111/2012);

- Provisions of this Law are applied also to the exchange of goods with Kosovo* for as long as the UN Security Council Resolution 1244 is effective;

- $\quad$ Provisions contained in rules related to foreign currency and taxes.

Article 309 of the Customs Law also specifies that its provisions shall apply mutatis mutandis to circulation of goods with Kosovo* as long as the UN Security Council Resolution No.1244 is effective with the aim to ensure orderly and uniform conduct its (Official Gazette of RS, 2010). Circulation of goods with Kosovo* is organized in the following way: when the goods from Kosovo* arrive outside Kosovo* the person who brought the goods shall submit to the relevant customs authority at the administrative line the transit document by which the goods are directed to the customs posts for further customs processing. The customs (transit) declaration is filled out pursuant to Articles 6, 7 and 14 of the Rulebook on the form, content, manner of submission and filling out the declaration and other forms within the customs procedure (Official Gazette of RS, 2010). At the customs post of destination the customs declaration is filled out pursuant to Articles 12, 13 and 14 of the mentioned Rulebook, in case that the Unified Customs Document (UCD) for release for free circulation, temporary import, active refinement, re-import, processing under customs control, customs warehousing and destruction of goods was submitted. The customs authority checks compliance with all required terms, including the bank guarantee, and calculates and charges the import fees where customs debt occurred. Goods arriving from Kosovo* to Serbia are released for circulation with VAT calculated and paid pursuant to the Law on Value Added Tax. For excisable goods coming from Kosovo* to Serbia, excise duties are charged pursuant to the Law on Excise Duties. The customs authority controls the submitted declaration to check whether the accompanying documentation is harmonized pursuant to the CEFTA agreement. CEFTA is the second biggest export market by importance for companies in Serbia after the European Union market. Products from Serbia are very recognizable at these markets. 
Kosovo* is member of the CEFTA Agreement (which on behalf of Pristina was signed by UNMIK). In case of goods subject to for mandatory prior approval of the authorized inspection service, such goods shall be allowed to enter Serbia only if such permission had been issued. Foreign goods shipped from Kosovo to Serbia are subject to paying customs fees, other import duties, excise duties and VAT (CEFTA, 2006).

Goods which have not commercial nature and which are carried by persons (passengers) are reported to the customs authorities and present subject to payment of customs duties, other import related fees, excise duties and VAT. The goods for personal use which passengers are carrying with them, are granted relief from customs duties and other import fees. The Regulation on Enforcement of the Law on Excise Duties in the territory of Kosovo* for as long as UN Security Council Resolution 1244 is effective, determines the ways in which this Law shall be implemented (Official Gazette of RS, Nos. 22/01, 73/01, 80/02, 80/02-suppl.law, 43/03, 72/03, 43/04, 55/04, 135/04, 46/05, 101/05-suppl.law, 61/07, 5/09, 31/09, 101/10, 43/11, 101/11, 93/12 119/12 and 47/13) in Kosovo in the period in which UN SC Resolution 1244 is in force (Official Gazette of $R S, 2013)$. Where the excise debtors from Serbia are directing excise goods for circulation to Kosovo*, the excise duties shall not be charged if these goods are carried to Kosovo*. A verified copy of the Unified Customs Document serves as proof that the excise goods were carried to Kosovo*. It confirms that excise goods left Serbia in Kosovo*, along with excerpts from the business account of the excise debtor proving that money from the business account of the receiver of excise goods was transferred to the account of the excise debtor (supplier of excise goods). Excises for goods shipped from Kosovo* for circulation in Serbia are calculated and paid pursuant to the Law.

The Customs Administration implements the Foreign Trade Law and the Decision also in case of control of circulation of the goods from Kosovo*. For circulation of goods from Kosovo*, participants in customs procedures submit to the customs authorities documents determined in the above regulations except in case of circulation of goods which are subject to phyto-sanitary, i.e. veterinary and sanitary control. In case of such goods exchanged with Kosovo*, the difference is that instead of the document approving the import of plants, pesticides or fertilizers, or the common veterinary entry document, minutes of performed controls issued by the phyto-sanitary i.e. veterinary inspection, must be submitted, according to Regulation on special terms applied to exchange of goods with the Autonomous Province of Kosovo and Metohija. Official Gazette of RS, Nos. 86/2010, 61/2013, 111/2013 and 17/2014. Decision on Determining Goods for Import, Export or Transit for which Certain Documents are Required is published in Official Gazette of RS, No. 32/2015, Ruling of the Customs Administration, Sector for customs operations and procedures 148-03-091-03-533/7/2016 of 2 November 2016.

Pursuant to the Instruction of the Ministry of Agriculture and Environmental Protection, the Plant Protection Directorate and Veterinary Directorate control the circulation of goods which are transported from or delivered to the territory of Kosovo* are subject to phyto-sanitary or veterinary inspection. Until 2012, the Certificate on internal circulation applied to all goods shipped to Kosovo*. However, today all goods entering from third 
countries and directed to Kosovo* must be accompanied with status-neutral documents. The goods enter the territory of Kosovo* through joint crossing points and are subject to inspection controls which should confirm that the goods did not remain in Serbia.

\section{Research Methodology}

In order to improve the business environment in the area of agribusiness it is necessary to identify and register the barriers to business operations. Considering the identified general and specific problems which legal persons in different fields of agribusiness are facing, it has been suggested how to solve these problems. The research offers insight into the real situation, it draws attention to ways in which trade is restricted and suggests how to eliminate barriers in order to realize normal movement of goods and services between Serbia and Kosovo*. To this end, a special part of the research refers to the analysis of the implementation of the CEFTA agreement between Serbia and Kosovo* and recommendations for removing delays in the implementation of signed agreements.

Based on the available data on active business entities that have business relations with Kosovo*, a representative sample of companies and competent institutions have been selected. The selection of target companies was defined according to the value of regular traffic with Kosovo* in 2015 and 2016, taking into account the greater geographical representation and diversification of the activity code. The methodological basis of the research was sending a specially prepared questionnaire to the addresses of 120 companies in the Republic of Serbia and Kosovo* as well as organizing and conducting interviews with companies in Serbia and Serbian companies in Kosovo*, as well as with relevant institutions. In order to obtain adequate conclusions, the in-depth interviews with the relevant institutions in Serbia were conducted. The relevant institutions are: Customs Administration (Ministry of Finance), Veterinary Directorate (Ministry of Agriculture and Environmental Protection), Border Phytosanitary Inspection (Ministry of Agriculture and Environmental Protection), the Office for Kosovo and Metohija of the Government of the Republic of Serbia. The analysis has used the primary data collected by the field investigation of customs checkpoints (customs office in Vranje) or joint points of the Končulj pass. The main sources of secondary data were the selected databases of the Serbian Chamber of Commerce, the Customs Administration and the World Bank.

The approach used during the research was aimed at presenting the real situation in the field and contribute to better informing business people about the business conditions at Kosovo*. By enhancing communication between businessmen, on the one hand and relevant institutions, on the other hand, significant results in the field of business environment ambitions can be achieved.

\section{Results}

During the research, 120 e-mails were sent to the companies in Serbia and 30 e-mails to the companies in North Kosovo*. Representative sample consists of 65 companies which answer the questions from the questionnaire. The structure of the representative 
sample shows that 10 companies are from Belgrade, 12 are form Vojvodina, 28 companies are registered in Central and Southern Serbia (Leskovac, Vranje, Bujanovac and Preševo) and 15 companies are from North Kosovo*. The specially prepared questionnaire consisted of 13 open-ended questions which are given below:

Table 1: The questionnaire in the research

\begin{tabular}{|c|l|}
\hline No. & \multicolumn{1}{|c|}{ Question } \\
\hline 1. & The name of the agricultural product that have been imported/exported. \\
\hline 2. & $\begin{array}{l}\text { Do you have any difficulties in obtaining documentation accompanying goods when } \\
\text { exporting/importing/transiting? }\end{array}$ \\
\hline 3. & $\begin{array}{l}\text { Besides the obligatory documents accompanying the goods when importing/exporting/ } \\
\text { transporting, do you require additional documents? }\end{array}$ \\
\hline 4. & $\begin{array}{l}\text { Have you encountered a situation that certain documents do not recognize you at } \\
\text { administrative crossings? }\end{array}$ \\
\hline 5. & $\begin{array}{l}\text { Do you have problems with administrative crossings with competent services (customs, border } \\
\text { police, veterinary inspections, phytosanitary...)? }\end{array}$ \\
\hline 6. & $\begin{array}{l}\text { Are the services and inspections at the administrative crossings coordinated and whether their } \\
\text { working hours are harmonized? }\end{array}$ \\
\hline 7. & $\begin{array}{l}\text { Are you facing double taxation of excise taxes and VAT, as well as the calculation of transport } \\
\text { costs higher than real ones - free assessment by the customs officer? }\end{array}$ \\
\hline 8. & $\begin{array}{l}\text { Have you encountered the situation that the services and inspections at the administrative } \\
\text { crossings violate the CEFTA agreement? }\end{array}$ \\
\hline 9. & Did you have any problems with the treatment of goods transit through Kosovo*/Serbia? \\
\hline 10. & $\begin{array}{l}\text { Did you have any problems with the collection of your receivables, in particular with regard to } \\
\text { insurance of business (bank guarantees, insurance of claims, etc.)? }\end{array}$ \\
\hline 11. & $\begin{array}{l}\text { Do you encounter a lack of adequate infrastructure in your day-to-day business (traffic, } \\
\text { inadequate conditions at administrative crossings, telecommunications, payment transactions, } \\
\text { insurance...)? }\end{array}$ \\
\hline 12. & $\begin{array}{l}\text { Have you dealt with unfair competition (the price of dumping, the favour of certain companies, } \\
\text { the hidden monopolies, irregularities in public procurement procedures, etc.)? }\end{array}$ \\
\hline 13. & Point out the barriers that you had in the store, which are not covered by this questionnaire. \\
\hline
\end{tabular}

The research process was performed by using two iterations. Firstly, questionnaire was sent to the selected companies by e-mail. Secondly, a deep interview was organized in order to define more detailed problems which related to the specific activity which companies deal with. During the research, 46 deep interviews with companies were conducted. The analysis of the obtained data was aimed to create clear picture of the business operations for companies which export/import/transit goods to/from the Republic of Serbia. A representative sample of companies is classified according to the official classification of activities according to the Statistical Office of the Republic of Serbia (Republic Institute of Statistics, 2018).

\section{Discussion}

In this part of the paper we give another view of the identified specific problems with which companies have faced in business. These problems are classified by type activity. Results obtained during the research show that in Sector: Agriculture, Forestry 
and Fishery (Field: Growing annual and biennial plants (growing of cereals, except for rice, leguminous and oleaginous plants), companies from Serbia which produce cereals, leguminous and oleaginous plants are facing the following problems while exporting to Kosovo*:

- It is necessary to register the varieties with Kosovo* institutions due to they do not recognize the existing registration in Serbia;

- Unfair competition. Local processing companies are protected and Kosovo* process or pressurize customers not to buy goods from Serbia.

- Reduced circulation and low price of wheat in 2016;

- Small number of phyto-sanitary inspectors in the field is additionally slowing down the circulation of goods.

In the Processing industry (Field: Food production), identified problems faced by companies from Serbia which produce and sell food products in Kosovo* refers to:

- Voluminous export documentation. Food export to Kosovo*is required the following documents: invoice, packing list, phyto-sanitary certificate, veterinary certificate and certificate of quality for the product. These are issued by authorized institutions, and shall not be older than six months. If the goods are exported to FYR of Macedonia, namely if they transit the territory of Kosovo*, apart from the mentioned documents it is necessary to also have the security certificate. The export of food products to the EU market is realized without the mentioned certificates. Specifically, the exporter issues the document which guarantees that the goods are safe in terms of health and which is sufficient for exporting to the EU market;

- Obtaining and harmonization of documentation. This relates, first of all, to the EUR1certificate of origin of goods and the veterinary certificate which is different for the internal and international circulation;

- Time and costs related to obtaining export documentation. It takes one to two days to obtain the necessary documents. For each export, the documents cost about 100 euros, i.e. each in voice must have a phyto-sanitary certificate, a veterinary certificate and the analysis of the quality of product. Goods are invoiced in euros, and the certificates are controlled by the Kosovo*side at the crossings;

- The declaration of products may be one of the barriers to unimpeded crossing. Companies use the formulation "distributor" on the declaration of the product, and not" exporter". The designation "Kosovo" is acceptable if it is not preceded by the word "Republic";

- Temporary blockage. A one-time ban on import of animal goods lasted for one year.

- Collection of claims is periodically impeded (impossible), due to insolvency of debtors;

- Collection of claims through out-of-court collaterals (blank bill) or enforcement based on credible documents is impossible once the debtor is blocked due to forced collection; 
- Due to afore mentioned facts, the export of food products to the EU market is simpler because it requires less documents and is cheaper when compared with the export of goods to the market regulated by the CEFTA Agreement.

Payment operations with Kosovo* functions by making payments mainly in advance and from the bank accounts, whilst in cases where payments are made in cash, these are most often illegal. As regards competition and conduct of competitors, major competitors for Serbian companies are local producers and companies in the neighborhood.

Most of the companies in the meat industry (branch: processing and conservation of meat and meat products) in Serbia do not export their products to the Kosovo*market. Processed meat from Serbia is neither present in big quantities in north Kosovo*. As the main reason mentioned are problems regarding harmonization of veterinary certificates, which has a discouraging impact upon business activities. Those who decide to export lasting and semi lasting meat products to the Kosovo* market are facing with the following problems:

- The major barrier is the non-harmonized veterinary certificate which is necessary for the circulation of goods of animal origin and is a mandatory part of the export documentation;

- Since July 2016 fresh meat and grilling meat is not exported to Kosovo*, because in force is a ban on export of meat to this market. The situation regarding the cattle's lumpy skin disease had caused a temporary ban of cross-border and partly also internal circulation of beef. However, the ban on exports to north Kosovo* applies both to pork and beef, and the result was that trucks were stopped in the intermediate zone. As regards the ban of exchange with other countries in the region, companies were informed on this by the Veterinary Directorate's document; as regards the ban of export to Kosovo* they received an oral on-site information from the veterinary inspectors;

- In order to realize the import, the customer must be registered with the institutions in Pristina and must have the license to import meat. The goods are directly delivered to shops in north Kosovo*, and payments were made in RSD;

- The sanitary examination is paid for each invoice at the administrative crossing (around 60 euros). Importers (shops) are associating and importing using one invoice in order to reduce costs for the sanitary examination of the goods;

- It is the practice that the exporter form Serbia pays VAT instead of the importer, and afterwards, during the business operation, the amounts are returned, which additionally complicates the procedure. For all goods, VAT is $19 \%$.

- It cannot be predicted how long the trucks are going to be kept there; when they are going to cross is unpredictable and uncertain. These goods have a short shelf life, and they are allowed to wait only for up to two or three days;

- Customers from north Kosovo* have a problem because they must obtain the documentation from authorities in Pristina. There are frequent changes of the documentation and the import license; 
- Kosovo* has closed its market for Serbian goods of animal origin which can be found only in traces. The consequence is that the market of Kosovo* has been given away to exporters from Slovenia, FYR of Macedonia and Montenegro. The market imposes as mandatory to obtain the Halal certificate, which makes the export more expensive but does enable a bigger market.

- The voluminous export documentation comprises: invoice in RSD without VAT, issued in the Serbian language, producer's specification, proof of origin of cattle, Unified Customs Document, CRM and certificate of quality of goods. The main problem with the placement of processed meat to the market of Kosovo* is the lack of a valid and harmonized veterinary certificate.

Companies are fully ready for placements to the Kosovo* market having in mind the high quality of products, health and safety requirements, business operations pursuant to HACCP principle sand respect for international quality standards ISO 9001, IFS and Global Gap. As regards exports to the EU market or to other countries signatories of the CEFTA Agreement (such as FYR of Macedonia) have not difficulties.

In the Processing industry (Field: Food production), identified problems faced by companies from Serbia which produce vegetable oils and animal oils and fat (such as: edible oils, margarine, vegetable fat, mayonnaise and delicacies based on mayonnaise.) refers to:

- Non-harmonized veterinary certificate. According to the representative of importers, if the merchandise is coming from Serbia, the Kosovo* side requests the veterinary certificate for the foreign market and treats the goods like foreign goods. At crossings, veterinary certificates are required although they are not mandatory for products containing less than $51 \%$ substance of animal origin (mayonnaise and margarine). Such practice, apart from Kosovo*, exists also in Bosnia and Herzegovina;

- The requested documentation (certificate of origin, certificate of health compliance and the set of laboratory analysis) has to be obtained for each individual export. The Certificate ofhealth compliance is obtained from authorized laboratories, and the rest of documentation is prepared in the company;

- Establishing the origin of the goods. It is necessary to ensure the origin of the goods at the customs terminal for every individual import, which is additionally complicating the procedure. Controls carried out by relevant services are too frequent.

Analyse of the production of dairy products shows that institutions in Serbia consider Kosovo* as an integral part of Serbia and export from Serbia to the territory of the Province is not possible. For the entrance of dairy products to the market of Kosovo* the Veterinary Agency of Kosovo* requests the export certificate issued by the Veterinary Directorate of the Republic of Serbia. However the relevant institutions in Serbia do not issue such licenses because they consider Kosovo* to be part of their territory. The identified problems in this area can be systematized as follows:

- Too expensive analysis of dairy products which have a short shelf life; 
- There is no harmonization of the export documentation and certificates accompanying the goods of animal origin are not recognized. There is dispute over the veterinary certificate accompanying the goods;

- The allowed concentration of aflatoxin in Serbia and the countries in the region is not harmonized. Since it is only Serbia which deviates in regulations in regard to the surrounding, it is necessary to harmonize the allowed concentrations of aflatoxin as soon as possible in order to be able to satisfy the needs of customers in the region (since 1 July 2014 the level of aflatoxin in Serbia was reduced by 10 times, from 0.5 to 0.05 micrograms per $\mathrm{kg}$, which is in accordance with EU standards).

The placement of dairy products to the CEFTA market is accompanied with frequent changes in procedures, frequent return of documentation for corrections etc.

In the branch: production of mill products, starches and starch products; companies from the Raska District, which produce mill products and sell them in Kosovo* are facing with the following problems:

- The Kosovo* side requests the goods to have the Kosovo* Certificate of health compliance, although companies own Serbian certificates and the Serbian HACCP;

- In order to run their business in north Kosovo*, companies must register Serbian and Kosovo import company. Thus one and the same company is importing (from the Serbian side) and exporting (from the Kosovo side);

- Due to double registration, there is double payment of taxes and registration of workers;

- The Kosovo* side requests the export certificate for the third country;

- Non-harmonized work of services at the crossings (for instance, if north Kosovo* should be entered on Saturday, the papers must be verified on Friday);

- The CEFTA Agreement is violated due to customs duties are paid for products which had been produced in Serbia;

- Big corruption of services at administrative crossings (monthly costs due to corruption are around 500 euros);

- Political pressures for the realization of public procurements.

Realization of exports in product categories such as: confectionary, candies, chocolates, pastry and flips, faced with declaration problem but it was successfully solved in the previous period due to cooperation with distributors in Kosovo* who obtain the adequate declaration.

\section{Conclusion}

The main aim of the research was to analyze possibilities for improving business operations between Serbia and Kosovo* and to harmonize procedures for obtaining certificates and documents accompanying the goods. The results show that there is a positive trend on the Serbian side, considering that export from Serbia to Kosovo is bigger in volume and has more favorable structure. In addition, goods exported from 
Serbia have higher level of processing in comparison to the goods imported from Kosovo*. It can be concluded that progress in improving conditions for doing business is evident. This is primarily a result of efforts by relevant institutions to simplify and facilitate export procedures, improved information and communication system, as well as simplified customs procedures.

This means specifically that the company which meets required criteria (bank guarantee, debt free, goods transported in adequately equipped vehicles etc.), is authorized to issue the necessary export documentation. There is no double taxation or paying of excise, and transactions with Kosovo* are treated as payment in foreign currency to other countries. In the first half of 2016, contentious issues related to integrated border management (IBM) were successfully resolved:

- Simplified electronic correspondence between the Customs Administration of Serbia and the Customs of Kosovo* is now realized only through the EU IMB Facilitation Office, without the intermediary role of the Ministry of interior affairs of the Republic of Serbia;

- Full implementation of the SEED system started, which enables systematic electronic data exchange between the Customs Administration of the Republic of Serbia and the Kosovo* Customs for all type of goods which are crossing the administrative line;

- After receiving the official confirmation from the European Union that procedures under Mutual Legal Assistance were changed, these cases were further dealt with by the Ministry of Justice of the Republic of Serbia;

- Harmonized certificate of pharmaceutical product (CPP). Relevant institutions in Pristina have issued first decisions on registration to drug producers for releasing circulation medicines in the territory of Kosovo*;

- Since 21 September 2015, the Republic of Serbia has started to issue entrance/exit documents and temporary plates for vehicles "proba" (temporary), with the validity of 60 days and with the possibility of multiple crossing at joint crossing points;

- At the joint crossing point Mutivode customs officers of both sides work seven days a week, from 8:00 a.m. to 8:00 p.m;

- Veterinary certificates for live animals are harmonized (except in case of breeding cattle) and became operational on $1^{\text {st } M a r c h ~ 2016 . ~ H a r m o n i z a t i o n ~ o f ~ c e r t i f i c a t e s ~ f o r ~}$ dairy products is pending, as well as certificates for meat products;

- The harmonized phyto-sanitary certificate has been successfully implemented at all administrative crossings at which the commercial transport takes place (Rudnica/ Jarinje, Merdare and Končulj/Bela Zemlja).

One of the problems that has not been solved is the inadequately determined customs basis for charging duties on construction thermal blocks. Namely, when the custom basis is established pursuant to the transactional value the result is a significant increase in product price and the reduction of the products' competitiveness. Besides, contrary 
to regulations and practice within CEFTA and the EU, products which apart from their vegetative ingredients also contain a certain (minimal) percentage of animal ingredients are required to have a veterinary certificate related to mixed products. Such practice is additionally slowing down the process of exchange and increasing the price of the product. There is also the problem with delivery of non-hazardous waste which relates first of all to paper, glass and metal waste. Companies from north Kosovo* cannot trade in Kosovo* unless they are registered with relevant institutions in Pristina, and businesses from north Kosovo* cannot import products from Serbia without having an adequate license issued by Kosovo* institutions. Also, entrepreneurs from north Kosovo*, who are not registered with the competent authorities, can sell their goods only to end customers because they are not in the fiscal system of Kosovo*.

Communication between Serbian and Kosovo* inspection services does not take place directly, but through EULEX as intermediary. In order to achieve further harmonization, meetings of the two sides with EULEX as intermediary are organized in Brussels every three months, while the activities related to harmonization and normalization of relations are further carried out on a monthly basis. However, further progress in the process of harmonization is unpredictable and it can be said that the solution for existing problems depends on the will and success of communication. Relevant authorities do not act in accordance with the government policies. The implementation of unilateral decisions, introduction of tariff and non-tariff barriers, and negative practice inflict great losses to companies. They significantly limit the placement of Serbian products, which have a long tradition and are recognizable in Kosovo. The Kosovo* market has a big potential and tertiary sector is dominant. This can be an opportunity for the Serbian production sector. The problems identified during the research show that the full potential in economic cooperation with Kosovo* is untapped. Considering the volume and structure of exchange of goods between Serbia and Kosovo*, liberalization of trade and harmonization of rule and using the tools for building the intellectual capital (Radenkovic et al, 2014), which regulate the circulation are in the interest of both sides. It can It is necessary to further increase institutional capacities and efficiency of relevant institutions with the aim to create an environment which will discourage alternative trade channels.

\section{Conflict of interests}

The authors declare no conflict of interest.

\section{References}

1. Bueno, E. (2001): “Creación, medición y gestión de intangibles: propuesta de modelo conceptual", en Formas y reformas de la nueva economía, Revista Madrid, monografía 1, pp. 43-48.

2. CEFTA, (2006): Law on Ratification of Agreement on Amendments and Adhering to CEFTA 2006. Available at: Law on Ratification of Amendments and Accession to the Central European Free Trade Agreement - CEFTA 2006. Available at: www.pks.rs 
3. Official Gazette of RS, (2010): Customs Law, Official Gazette of RS, No. 18/2010 and 111/2012.

4. Euroforum Escorial (1998): "Medición del capital intelectual. Modelo Intelect", I.U. Euroforum Escorial, Madrid.

5. Martín de Castro, G.; Navas López, J.; García Muiña, F.; López Sáez, P. (2005),“A new model to measure and manage intellectual capital" in Sunder (Ed) "Business performance measurement: intellectual capital-valuation models". Le Magnus University Press, Hyderabad, India.

6. Radenkovic, S.D., Devedzic V, Jovanovic, J., Jeremic, Z (2014): Content and Knowledge Provision Service - a Way to Build Intellectual Capital in Learning Organizations, Knowledge Management Research \& Practice (KMRP) Special Issue: Towards an Intellectual Capital-Based View on the Firm, Palgrave Macmillan, August 2014, Volume 12, Issue 2, ISSN: 1477-8238.

7. Republic Institute of Statistics, (2018): Republic Institute of Statistics of the Republic of Serbia, Classification of Activities. Available at: http://webrzs.stat.gov.rs/

8. Official Gazette of RS, (2013): Regulation on Enforcement of the Law on Excise Duties in the Territory of the Autonomous Province of Kosovo and Metohija for as long as UN Security Council Resolution 1244 is effective, Official Gazette of RS Nos. 111/13, 6/14.

9. Roos, J., Roos, G. L. Edvinsson, L. and Dragonetti, N. C. (1997), Intellectual Capital: Navigating in the new business landscape, Macmillan, London.

10. Spender, J.-C. and Grant, R. M., Ed. (1996), Knowledge and the Firm, Special Issue, Strategic Management Journal, Vol. 17 No. 2.

11. Stewart, T.A. (1997): Intellectual capital. The new wealth of organizations, Nicolas Brealey Publishing, Londres. 